Article

\title{
Mapping the Palimpsest of Milieus: Towards a Shared Project on the Open Spaces of the Plaine Lyon-Saint-Exupéry
}

\author{
Alexandre Callens \\ IPRAUS/AUSSER Research Unit, Paris-Belleville School of Architecture, 75019 Paris, France; E-Mail: alex.callens@gmail.com
}

Submitted: 15 January 2020 | Accepted: 14 May 2020 | Published: 30 June 2020

\begin{abstract}
This article examines the tools and methods that contribute towards the development of open-space projects in urban countrysides as part of land-use planning processes. It focuses on the creation of a support to encourage dialogue between ecology and landscape architecture professionals, in relation to their common interest in the history of the territories they are analysing. Based on the notion of palimpsest, we propose an original methodology for the cartographic representation of milieus, designed as a tool for interprofessional work. We conducted an experiment within the operational context of the Plaine Lyon-Saint-Exupéry so as to set out this method of data and map production on GIS software, reinterpreting the historical atlas of the Canton of Geneva (Corboz, 1983; Léveillé et al., 1993). We will see that these cartographic representations allow for unique readings of planned territory in order to imagine its future. For ecology and landscape professionals working on the open spaces in question, they contribute to develop complementary project intents and new modes of exchange with local actors with regard to its co-construction. The palimpsest mapping tool may therefore be defined as an 'intermediary object' for a shared multifunctional project on open spaces.
\end{abstract}

\section{Keywords}

cartography; interprofessionality; landscape architecture; landscape ecology; open space; periurban; regional planning; territorial planning; urban countryside

\section{Issue}

This article is part of the issue "Territories in Time: Mapping Palimpsest Horizons" edited by Chiara Cavalieri (UCLouvain, Belgium) and Elena Cogato (EPFL, Switzerland).

(C) 2020 by the author; licensee Cogitatio (Lisbon, Portugal). This article is licensed under a Creative Commons Attribution 4.0 International License (CC BY).

\section{Introduction}

For urbanists, open spaces are study objects. When planning urban countrysides marked by the development of built-up areas and infrastructures that fragment these spaces, their valorization is deemed essential to territorial restructuring (Donadieu, 1998; Magnaghi, 2014; Sieverts, 2003). For this purpose, different types of spaces are taken into consideration, ranging from unbuilt spaces within urban envelopes to agri-natural spaces.

The multifunctionality of open spaces, including ecosystemic services, are among a territory's main resources for a living environment, biodiversity, agricultural production, safe water adduction, among others. Nowadays, projects relating to these spaces call upon different types of knowledge and challenge the implemen- tation of inter-professional work. Our argumentation looks more specifically at the fields of landscape ecology and landscape architecture, respectively defining them as a scientific approach to ecological networks and as a project approach linked to socio-cultural processes (Décamps \& Décamps, 2004; Nassauer, 1992). We consider the transversality between these areas of knowledge to be essential to the development of a multifunctional project and to commitment from territorial actors.

Our reflection will focus on the development of tools and methods that will create favourable conditions for this interprofessional work. More specifically, it will be a case of developing representation supports, an area of interest in urbanism and landscape architecture (Loubière et al., 2007; Pousin, Marco, BertaudièreMontès, Barthélémy, \& Tixier, 2016). We will look at 
these in relation to the sociology of innovation which studies modes of dialogical exchange between different actors (Callon, Burchell, Lascoumes, \& Barthe, 2011). These representations are designed as 'intermediary objects' characterized by their ability to link heterogeneous social and professional worlds (Vinck, 2009; Vinck \& Jeantet, 1995).

The palimpsest refers to the historical depth of the constitution of a territory (Corboz, 1983) and we identify it for its capacity to interest different types of knowledge. Inter-professional work might be federated around this territorial heritage, between nature and culture (Poli, 2018).

Regarding these aspects, our article proposes a methodology for mapping the palimpsest of milieus, in order to produce 'intermediary objects' that contribute towards interprofessional work on the open spaces of urban countrysides. To this end, we will reinterpret the historical atlas of the canton of Geneva (Léveillé et al., 1993) as it relates to our objectives.

To develop this method, we will rely on a test conducted within the operational context of the Plaine SaintExupéry located in the Lyon metropolitan zone in France. We will see that it allows for unique readings of planned territory in order to imagine its future. For ecology and landscape professionals working on the open spaces being studied, these cartographic representations contribute to develop complementary project intents and new modes of exchange with local actors with regard to its co-construction. A retrospective reading of the history of open spaces opens the way for a prospective narrative (Sgard, 2008).

We will develop our argument in three stages. First of all, we will explain how the question of time can make it possible to link ecological and landscaping approaches in the context of planning open spaces in France. We will then explain the methodology used to create these maps of the palimpsest using GIS software and the production of the corresponding temporal data. Finally, we will look at how they can be a tool with which to read open spaces and define hypotheses as to their future as part of an inter-professional and multi-actor process.

\section{The Temporal Dimension for the Development of Interprofessional Work on Open Spaces}

\subsection{The Landscape Ecology Approach}

The landscape ecology approaches were developed in professional practice alongside planning policies on ecological networks. The latter began with the Convention on Biological Diversity adopted on an international scale in Rio de Janeiro in 1992. Various ways of including them in territorial planning have been developed in European countries (Jongman, Külvik, \& Kristiansen, 2004). In France, it was to a large extent the Grenelle laws of 2009-2010 that introduced themed regional planning: the regional scheme for ecological coherency
(SRCE). This was included in lower-level general planning documents such as the territorial coherency schemes (SCOT). A certain number of financial assistance contracts were implemented to support local ecological restoration projects.

This policy focuses on conceptions and methods borrowed from landscape ecology and considers open spaces as structures with which to tackle biodiversity loss (Ahern, 1991; Burel \& Baudry, 1999; Forman \& Godron, 1986). Indeed, one of its founding texts talks about the identification of "ecological corridors" to allow a given species to move between favourable milieus known as "reservoirs of biodiversity" (MEEDDM, 2010, p. 10). This mobility allows fauna and flora to maintain a sufficient living space when faced with the fragmentation of their natural habitats as a result of anthropic activities (urban sprawl, infrastructures, intensive farming, etc.). Ecology professionals define reservoirs by essentially basing themselves on pre-existing protection and naturalist inventory perimeters. For the corridors, different methods exist, mainly using GIS mapping, which can be applied on a regional (1/100000) or local (1/10000) scale. Environmental permeability analyses are common (Amsallem, Sordello, Billon, \& Vanpeene, 2018). To achieve this, maps of current land occupation are created, generally using GIS data produced by National Geographic Institute (IGN), along with some additional pre-existing naturalist data. These maps thus define the main categories of the mosaic of ecological milieus, each being allocated a permeability coefficient per species guild, i.e., per wildlife group presenting relatively similar habitats and modes of displacement. After modelling and simulating fauna displacements, this makes it possible to determine existing corridors linking biodiversity reserves, and then to guide the restoration operations that need to be undertaken to improve the situation. These GIS maps serve as a basis for discussions with local actors.

At the launch of the Grenelle laws, thought was given to the term 'landscape' in these socio-cultural and economic dimensions, in relation to the elements that constitute the ecological network, such as hedges, riverine forests, ponds, etc (MEEDDM, 2010, pp. 27-28). Yet no project methodology was mentioned in relation to this notion, which disappeared from the implementing decrees and circulars. The guides published under these laws refer to landscape ecology methods, without creating any tranversality with those relating to landscape (APCE, 2016, pp. 10, 13).

\subsection{The Landscape Architecture Approach}

Throughout the history of regional planning, landscape architects have developed different methods for dealing with landscape quality, a goal that was indeed been confirmed by the European Landscape Convention in 2000. Open space is seen as a structure for organising urbanisation and contributing to the well-being of inhabitants. 
In France, we can place the beginning of such landscaping approaches at the start of the 1900s with J. C. N. Forestier's (1906) "park system" conceptions, inspired by F. L. Olmstead. However, the methods currently used were developed in the 1960s-1970s in the regional organisations for metropolitan study and planning (OREAM) that were tasked with creating the metropolitan area scheme (SDAM). This organisation brought together professionals from different backgrounds, and young landscape architects such as Jacques Sgard and Pierre Dauvergne conducted studies on large landscapes. In particular they described the project to be undertaken with regard to the 'green corridor,' 'green separations' or 'green belt' announced in the metropolitan area scheme and in lower-level planning documents, as town planning and development schemes (SDAU). One of the methods defined was the identification of landscape units working on socio-cultural processes related to spatial landscape structures (agricultural spaces, transitions with urban spaces, reliefs, afforestations, watercourses, etc.). Geographers, agronomists, ecologists, sociologists and other experts took part in order to integrate the different functions of these green continuities (OREALM \& PAYSA, 1975; Zarmati, 1980).

These inaugural approaches were developed alongside landscaping policies, driven in particular by the 1993 landscape law. This can be seen in the landscape atlases, plans and charts which are becoming more and more widespread, contributing to projects for territorial enhancement. Guides provide details of the methodologies used (Pernet, 2014, pp. 57-89; Raymond, Luginbühl, Seguin, \& Cedelle, 2015). Maps, block diagrams, sketches, photos, etc. are used as representation supports for discussions with local actors. Hand drawing is the preferred technique for expressing landscape ambiances, cartographies included. However, current reflections relate to representations from GIS techniques (APCE, 2018).

Current general regional planning documents such as territorial planning schemes and regional schemes for territorial planning, sustainable development and equality (SRADDET, which integrate and replace the SRCE) refer to these landscape approaches. They are clearly defined in such a way as to distinguish them from landscape ecology approaches (Raymond et al., 2015, p. 64).

\subsection{The Potential of Time to Link Ecology and Landscape}

Landscape ecology and landscape architecture approaches focus respectively on natural dynamics and socio-cultural processes. Methods were developed independently. However, a transversal and multifunctional approach is a major challenge when attempting to act effectively on open spaces (Décamps \& Décamps, 2004; Nassauer, 1992). With this objective in mind, and in addition to these specific methods, we propose to develop a palimpsest mapping project as a support for inter-professional dialogue.
We were interested in the temporal dimension because it is something of interest to both ecologists and landscape architects. Indeed, in order to develop a project, landscape architects need to understand the past and the socio-cultural depth (Pernet, 2014, pp. 76-83; Raymond et al., 2015, pp. 27-28, 41-45). Ecologists, for their part, are interested in historical approaches to existing milieus in order to better characterise them and better envisage modes of ecological restauration (Girel, 2006; Lefeuvre, 1999).

We understand this temporal and heritage-related dimension through the analogy of the palimpsest as presented by Corboz (1983). The territory is seen as an accumulation of traces resulting from processes of addition and deletion. It conveys a meaning and a collective imaginary that are a combination of multiple factors, natural and human, material and immaterial. For Corboz, an attentive and nostalgia-free understanding of the dynamics of transformation allows one to intervene intelligently in the space. This approach considers the 'territorial heritage,' including places that are run down, in order to project a valorisation of the territory (Poli, 2018, pp. 102-104).

Our approach to the past will be restricted to the long period of metropolitan regional planning and its adaptations at lower scales, i.e., between 1960 and today. This was a significant period of open-space planning, also accompanied by major environmental deterioration. We therefore feel that it is important to provide new knowledge of this past planning in order to raise questions concerning the desired effects of current planning and ongoing projects. The notion of palimpsest, characterized by the joint presence of accumulations and deletions, guides the development of this knowledge. The lengthy duration of the constitution of the territory is approached through the heritage that existed in the 1960s and through the way it has been considered until today. An extension of our work, which we will not discuss here, might be to place the lengthy planning within a longer temporality.

We chose to represent the palimpsest using GIS cartographic software. This is a standard technique in the field of urban planning, which makes it a relevant interprofessional project work tool. We will focus on the possibilities of visual representation afforded by GIS in order to interest both ecologists and landscape architects. As we will see, we will include components of the territory that are of interest to them. Moreover, we will use a graphic interpretation to relate the complexity of the territorial palimpsest. Ecologists will be able to see a representation created through familiar technology, while landscape architects will be able to see the expression of landscape patterns through a digital drawing, supplementary to the image drawn by hand (Tiberghien, 2013). This cartographic work is therefore of a 'descriptive' nature in the sense proposed by Corboz (2001). It proceeds from a selective reading of the territory in order to be coherent with the professional cultures concerned and is project-oriented. 


\section{Method for Mapping the Palimpsest of Milieus}

\subsection{Zone of Experimentation: The Plaine Lyon-Saint-Exupery}

The Plaine Lyon-Saint-Exupéry is the study zone for which we will develop and test the palimpsest mapping method, in line with our research orientations. This urban countryside was chosen because it is the object of an open-space project process involving landscape and ecology professionals, and because it is a space planned over a long period of time.

Since the 1960s and the development of its planning, this area has been identified as strategic for the development of the Lyon airport platform (Dugua, 2015, pp. 541-571). It is located on the border between three departments (Ain, Rhône and Isère). There are currently four planning documents related to it on a territorial scale (SCOT), themselves framed by a regional territorial planning scheme (DTA) modified in 2015 following several studies (Dugua, 2015, pp. 610-649, 687-753). The challenge is to structure the development of this strategic area-including, in particular, the extension of the airport, the creation of railway infrastructures and business zones, etc.-around agri-natural open spaces with ecological and landscape functions (Figure 1). These orientations are consistent with other regional planning documents (SRCE and SRADDET). More specifically, landscape and ecology professionals are interested in this area. In the region, within government departments, the Plaine Saint-Exupéry is a pilot site for a landscape approach that takes ecological networks into consideration (APCE, 2016, p. 36). Moreover, as an extension to the Rhône-Alpes SRCE, this territory was the object of two pre-operational studies on ecological networks, each of which was driven by a river syndicate (or equivalent) in order to specify ecological restoration actions with a view to obtaining a financial assistance contract (ECOVIA, 2016; TEREO, 2016).

However, actions on open spaces show a lack of joint work between ecology and landscape professionals. Indeed, ecological methods are the only ones to be developed in the pre-opérational studies. Actors involved in environmental protection, territorial planning and farming have discussed modelled ecological networks in order to jointly define the work that each profession can carry out: the construction of wildlife passageways at infrastructure level, differentiated green space management, hedge planting, creation of open habitats or ponds, reconfiguration of watercourse banks, etc. No landscape professionals took part in these studies. Yet, during an interview in 2017, the two technicians in charge of studies on the Bourbre Basin and the eastLyon region pointed out that once the action contract

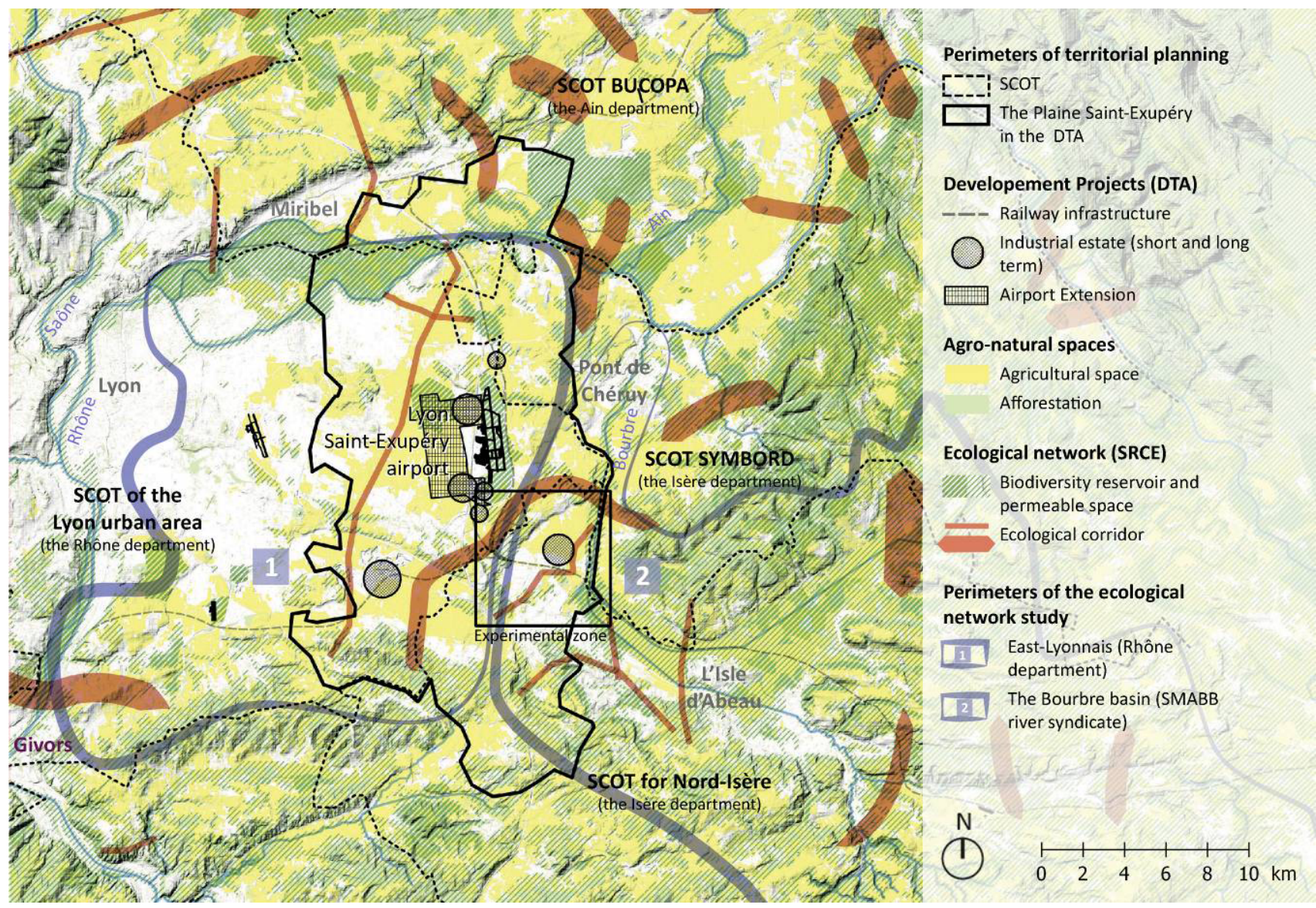

Figure 1. Plaine Saint-Exupéry: Perimeters for planning, ongoing projects and environmental challenges. Source: Author. 
has been set in motion for a five-year period, lengthy discussions with the various municipalities, operators, land owners and/or administrators will be required in order to specify possible actions. Generally speaking, the ecological theme is not enough to mobilise local actors. Landscape is a useful entry point. It is for this reason that the Bourbre river syndicate (SMABB) will seek landscape expertise from CAUE Isère (consultancy, architecture, urbanism and environment) in addition to ecological consultancy with CEN Isère (natural space conservatory). While the partnership with the CEN is commonplace in contracts resulting from the SRCE, the CAUE partnership is the first of its kind in Isère and their role is still being defined. No method or tools have been prefigured to link the ecological and landscape aspects. This is therefore a useful context for testing our approach.

With our cartographic work, we wish to take a step back from the open spaces of the Plaine Saint-Exupery regarding ecological and landscape changes over the long period of planning, on the hypothesis that this will contribute towards an inter-professional dialogue. To this end, we began by analysing the territory's planning documents, of which there are many and which have different approval dates due to the territory's administrative fragmentation. To give ourselves an overview, we set reference years at 15-year intervals to distinguish between the different generations of these documents
(Figure 2). For each one, we identified the main ideas relating to open spaces (Autran, 2004). Around 1975, the Plaine Saint-Exupéry was identified as a strategic part of the 'green belt' that separated Lyon's urban area from two new towns. It was a case of restricting the growth of the urban area, of protecting and modernising periurban agricultural zones (irrigation, land consolidation, etc.) and of inserting metropolitan infrastructures such as the airport. These orientations were set out at a territorial scale and prefigure the future limits of planning documents (Figures 1 and 2). A reflection on landscape and the environment was discretely presented during this period, via the notion of 'living environment' and was reaffirmed in the 1990s with a focus on landscape approaches. A proposition was made to reveal the territorial geography (waterways, watercourses, reliefs, etc.) for the Lyon urban area (Gras, 1995). A landscape map was created for the Isle d'Abeau territory so as to link the planning projects to the relief and vegetation of agri-natural areas (Bédarida, 2002). In addition, the Rhône-Alpes landscape observatory relayed these approaches on a regional scale as from 2005. The ecological dimension was to be highlighted with the regional planning in the mid-noughties as part of the multifunctional design of a "green mesh network" (Préfecture de région Rhône-Alpes, 2006). The Plaine Saint-Exupéry, which was currently under development, became part of the urban

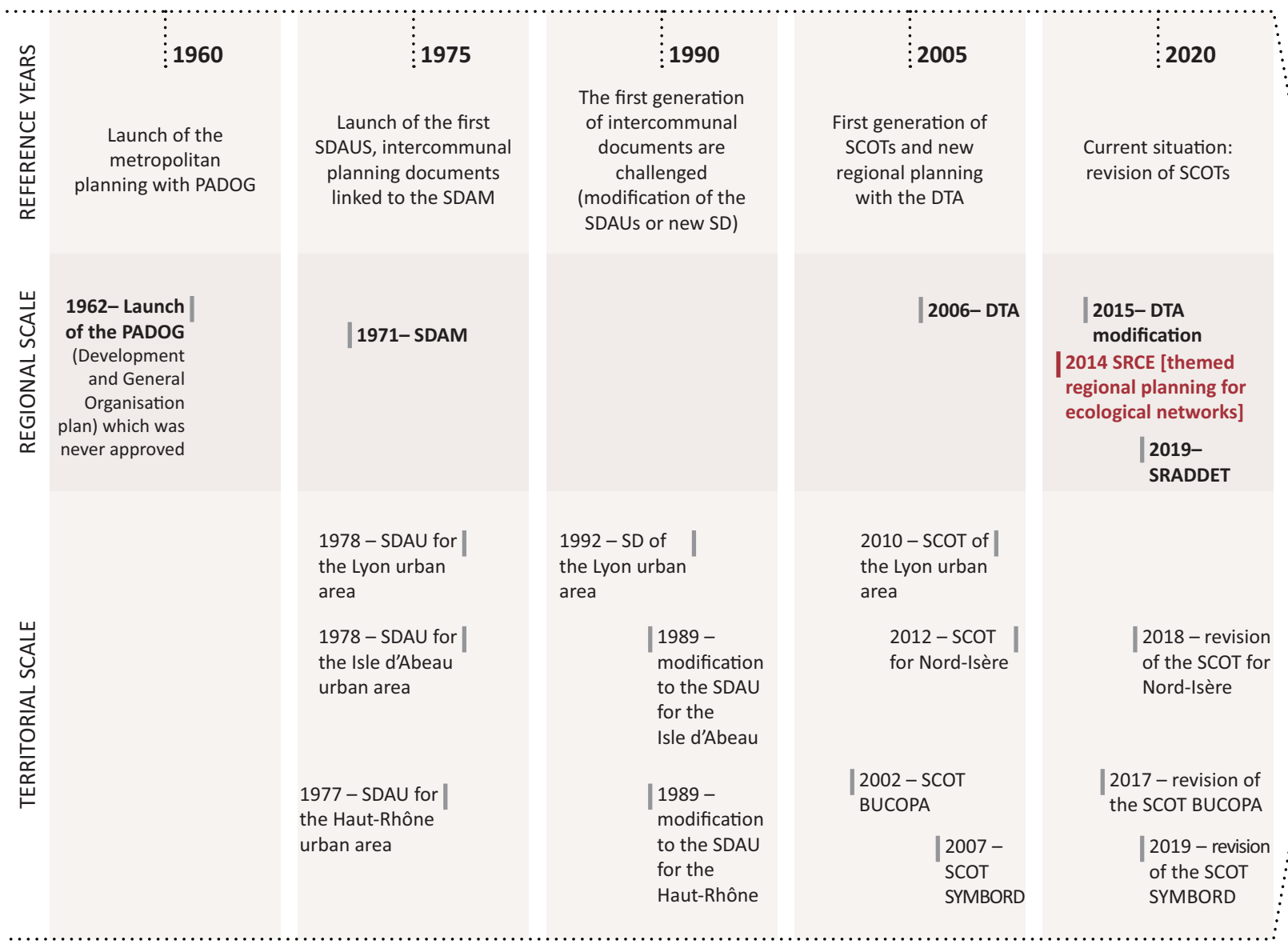

Figure 2. Planning documents for the Plaine Saint-Exupéry territory. Source: Author. 
area 'green belt,' concerned with the challenges of landscape requalification, ecological functionality, the development of environmental farming practices and the protection of water resources. These orientations were set out on a territorial scale, i.e., between the commune and the region. These issues were updated in accordance with recent revisions or modifications to the planning documents, bringing us to the current problems with open spaces, as seen above.

\subsection{Reinterpreting the Historical Atlas of the Geneva Canton}

Our cartographic construction draws on the historical atlas of the Geneva canton (Léveillé et al., 1993). Part of the latter can be accessed online at SITG-Le Territoire Genevois à la carte (Cartes professionnelles/patrimoine: 'Territoire 1800' and 'Territoire XIX-XX'). It superimposes the 1991 cadastral plan onto that of the beginning of the 19th century, thus defining the 'permanencies,' 'persistences' and 'disappearances.' This hand-drawn representation, which includes urban countrysides, offers a simultaneous visualization of the past and present of the different components of the territory (parcels of land, watercourses, roads, buildings, vegetation, etc.). We feel these characteristics to be of interest regarding innovation in current research on the historical GIS mapping of open spaces. The latter tend either to separate the visualization of elements that have appeared and disap- peared (Franchomme \& Dubois, 2010) or to give a quantitative representation per pixel (Bellec, Gauthiez, Fenet, \& Kaufmann, 2019), without expressing complex spatial patterns. Moreover, such research generally focuses more on areas of dense urban agglomeration (Khirfan, 2010), or on specific agri-natural spaces (Franchomme \& Dubois, 2010), than on urban countrysides with the specific relationhips between open spaces and the built environment.

We therefore propose to reinterpret the cartographic work carried out in Geneva in the 1990s. To achieve this, we adapted many aspects relating to the context on which we are working. First and foremost, we represent the elements that are significant for landscape ecology, i.e., those that contribute towards the fragmentation of natural habitats (urbanised spaces, infrastructures, etc.) and those that make up the mosaic of the ecological network's milieus (grasslands, hedges, afforestation, waterways, bodies of water, etc.). As constituent parts of territorial morphology, these components also have meaning for the landscape. Secondly, although we are inspired by permanencies, persistences and disappearances, we do not make the distinction between 'permanence' and 'persistence,' which we group with the term 'continuance.' We also add the term 'appearance' (Figure 5). Finally, this mapping was performed at the same $1 / 10000$ scale which is also commonplace for modelling landscape ecology when defining local actions.

The reference area is that of the Plaine Saint-Exupéry, but this article will focus on an open space that links a
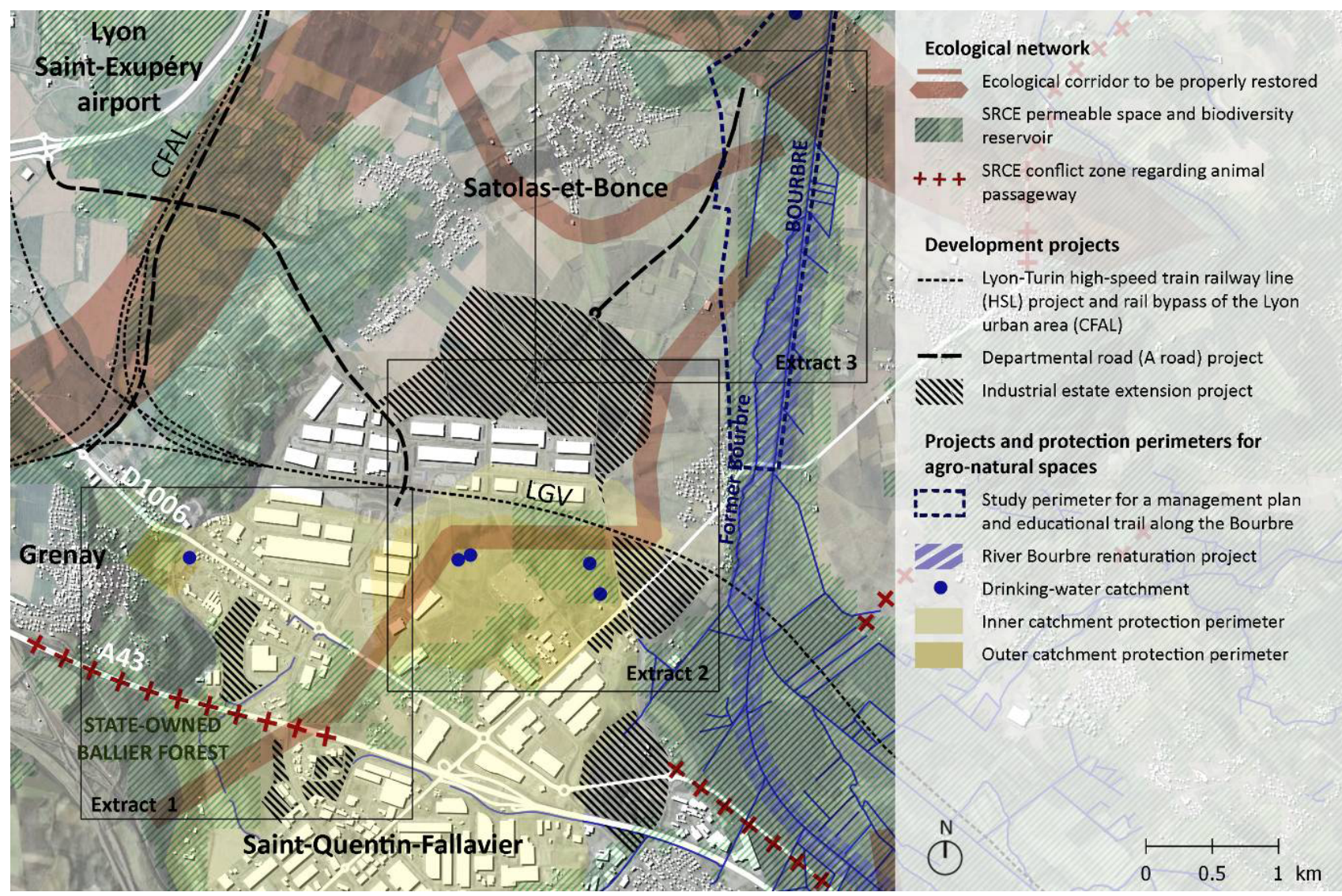

Figure 3. Experimental zone, ongoing planning projects and environmental challenges. Source: Author. 
reservoir of biodiversity in the Bourbre marsh to a stateowned forest (Figure 3). This particular space is representative of the broader challenges that the territory in question poses, as it combines issues of ecological functionality, landscape quality, planning, agricultural protection and conservation of water catchments.

\subsection{Data and Map Production Method}

GIS mapping involves the manipulation and production of digital data. The first stage of our GIS work consisted of collecting the materials needed.

First of all, based on the years of reference for the different generations of planning documents and, depending on their availability, we chose old maps and aerial views from the National Geographic Institute (Figure 4). They are either georeferenced on GIS after digitalisation, or else loaded via National Geographic Institute's web map service flow.

We then collected three types of GIS Shapefile and Raster data relating to the current situation:

- The 2016 land registers containing information from the directorate general for finance.

- The 2016 graphic parcel register (registre parcellaire graphique, RPG) produced by the service and payments agency listing the agricultural land parcels being farmed.

- The National Geographic Institute's 2016 largescale repository (référentiel à grande echelle, RGE) containing the BD Topo, which describes the elements of which the territory is comprised and its infrastructures (roads and railway lines, buildings, hydrographics, etc.), and the large-scale repository Alti made up of a digital terrain model.

One final source concerns georeferenced documents and GIS files from various ongoing actions and projects (urban planning, zones protecting water catchments, renaturation project, etc.). These were supplied either by local actors, or else downloaded from the operators' websites.

In addition, we carried out field work, walking the land, taking photos, surveying and talking to inhabitants, farmers, elected officials and technicians from local communities. This work was useful in gaining an understanding of the process involved in transforming the territory, and also helped us to interpret the aerial views by referring to existing studies and to the collective memory of spatial transformations.

The second stage consisted of producing new shapefile mapping data for the selected territorial elements, by giving them temporal information. For each of these elements, we identified the most pertinent sources to use, the idea being to achieve an equivalent level of accuracy for each period, with the objective of creating a $1 / 10.000$ map.

We generally use BD Topo shapefiles, to which we add a time-dedicated field with QGIS. This gave us a working base that contained all of the territory's existing components (roads, railway lines, airports, electric lines, waterways, surface water, hedges and woods). We then dated their appearance by using photographs and historical maps to go back in time. We redrew certain inaccurate aspects of the BD Topo, such as hedges and woods. Finally, we did the reverse, working from
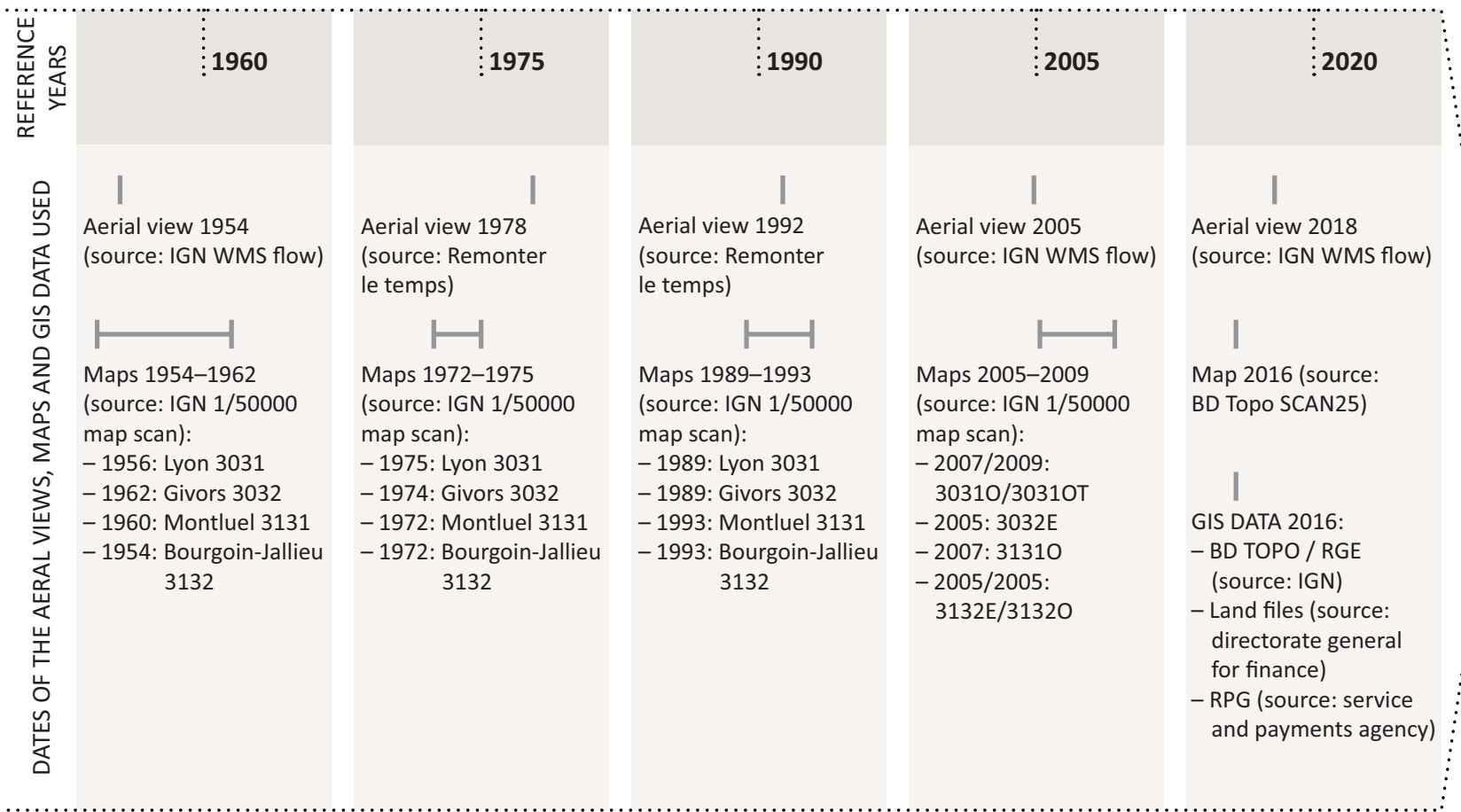

Figure 4. Reference dates for Plaine Saint-Exupéry planning and the sources used for mapping. Source: Author. 
1960 to the present day, drawing and dating the components that had disappeared, or which had appeared and then disappeared.

We also used other sources. Regarding the urbanised spaces, the land registry files containing the building permit applications allowed us to date the urbanization of agri-natural open spaces. For the open spaces, the RPGs provide precise information on cultivated zones (crops, grasslands, etc.), but do not make it possible to go back in time, with the exception of grass filter strips, as they only came into being recently, with the Grenelle II law. So, in order to have the same level of information for all of the reference dates, we mainly used aerial photographs. These views were also used to identify the different types of sub-surface exploitation.

While certain elements were relatively easy to identify with the abovementioned sources-roads and railway lines, infrastructures, etc. - others required interpretation, and were subject to a possible margin of error. In terms of the agri-natural components, this essentially meant the hedges and open habitats. This is due to the fact that in poor-quality aerial photos, crops and certain grasslands can look very similar, and the shadows from hedges can be confused with those caused by herbaceous formations of embankments or ditches. In terms of urbanised zones, this mainly related to built-up parcels, due to the incomplete nature of the land register, the absence of information on the constructed parcels whose buildings had been destroyed and the poor definition of old aerial photographs with which to complete it.

We then produced a final data type, relating to the ongoing projects. As the materials gathered so far were mainly JPEGs and PDFs that had then been georeferenced on GIS software, we created a shapefile layer in order to redraw the footprints of the projects (urbanisation perimeter, infrastructure layout and perimeter of action on the agri-natural spaces).

The final stage consisted of using the resulting shapefile database to create two palimpsest mapping panes. These mappings echoed those in Geneva's historical atlas, highlighting on the one hand "the superimposition of the Napoleonic cadastral map onto the current overall map" and "the territorial formations-transformations of the 19th and 20th centuries" on the other (Léveillé et al. 1993, pp. 18-21). In our case and as the legend explains (Figure 5), they will explore:

- The differential between 1960 and the present day and the forthcoming projects, underlining the continuances that are essentially shown in dark shades. This pane consists of one map.

- The differential that we identified by planning period (1960-1975, 1975-1990, 1990-2005, 2005-2020), underlining the changes (appearances, disappearances) by showing them in a dark shade. This pane is composed of four maps.

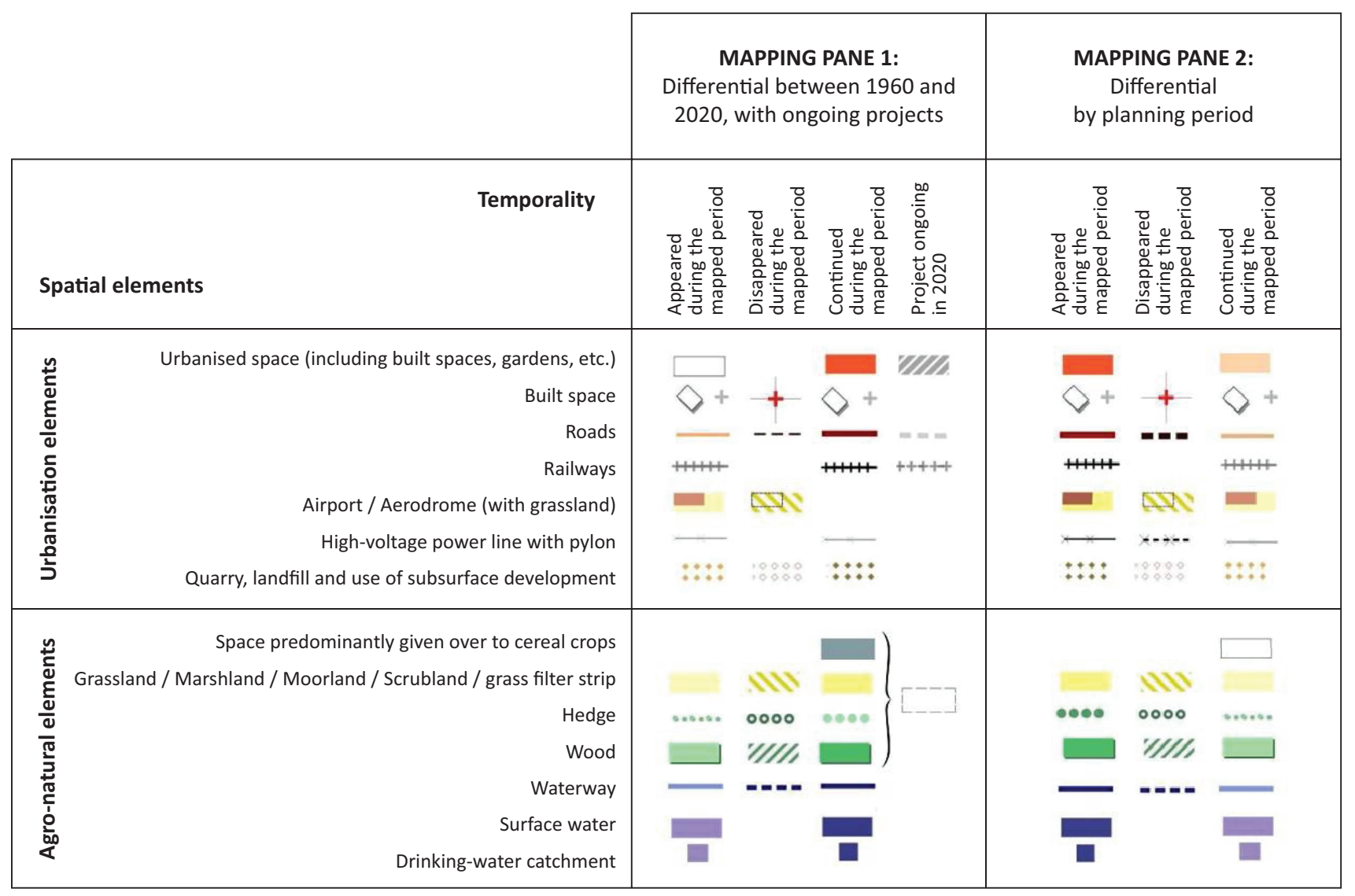

Figure 5. Legend for the mapping of the palimpsest of milieus. Source: Author. 
The first mapping pane allows us to see the territory's transformations and continuances in a succinct manner, and the second pane lets us view the details of these changes, over shorter periods of time of the territory (Figures 6, 7 and 8).

\section{A Visual Tool with Which to Develop a Shared Multifunctional Project}

\subsection{A Visual Support for Reading the Evolution of Planned Open Spaces}

This mapping tool allows one to read and assess the planning of open spaces and of land. To achieve this, the ecological habitat and landscape transformations revealed by the mapping panes are compared with the different orientations of the successive planning documents. This is what we propose to do by describing the evolution of an open space on the linear of an ecological corridor also concerned by landscape quality issues. Three extracts from the palimpsest mappings (Figures 6, 7 and 8) allow us to identify spatial transformations that are potentially significant for landscape and ecology professionals. Characteristic aspects of urban countrysides are observed in detail: infrastructure transition, urban sprawl, intensive agriculture, relics of remarkable natural areas, etc.

The first extract (Figure 6) allows us to see the permanent nature of the wooded hillside in Grenay (Figure 6, no. 1 ) and the resulting transformations relative to the appearance of a roadway infrastructure followed by the industrial estate. The motorway, construction of which began before the 1970s planning documents were approved, takes the place of an old country road, thus removing the pre-existing local links between hamlets and villages (Figure 6, no. 2). Open habitats are structured here and there, including along the route through the wood (Figure 6, no. 3). Flowing from the hillside and prior to its infiltration by a gravel soil, a stream was culverted to cross the motorway and a retention basin was created nearby (Figure 6, no. 4). The industrial estate, one of the largest in Europe, began to develop in the 1970s in line with the Isle-d'Abeau's 1970s planning document. In an annex, the latter presents a 'green SDAU' recommending that it be created outside the hillsides and morainal knolls. It was developed on flat land. The existing roads and tracks disappeared (Figure 6, no. 5). A new main road served this urbanisation and ungrassed retention basins were organised on either side, as an extension of the stream (Figure 6, no. 6). In addition, we can see that a railway line, relatively unused nowadays, was laid at the foot of the hillside and crossed over the motorway in the 1970s-1980s (Figure 6, no. 7). The landscape and ecological orientations found in the planning documents of the 1990s-2000s translated into the roads and retention basins being landscaped with lines of plants and vegetation (Figure 6, no. 8).

The second extract (Figure 7) extends the observations concerning the deletion of previous territorial struc- tures, made beforehand with regard to the industrial estate, and completes it with a description of the forest park. As from the 1990s, new roads, independent of their predecessors, were built to serve recent industrial buildings and logistics. This either led to ruptures in the side-street network-with the dead-end roads on the outskirts of these developments (Figure 7, no. 1)or to the creation of roundabouts at strategic crossroads (Figure 7, no. 2). Before and during the construction of the industrial estate, the old hedge structures were removed (Figure 7, no. 3) and then replaced as from the 1990 s by plantations that landscaped the main roads and the new roads servicing this urbanized space (Figure 7, no. 4). The landscape and ecological orientations (fauna, flora, groundwater protection) that had begun to assert themselves in the 1990s-2000s with the Isle-d'Abeau landscape plan in particular, came to fruition with the forest park. This is located level with the catchment protection perimeters and underneath the high-voltage lines (Figure 7, no. 5), while remaining within the operational boundaries of the industrial estate. The 'green SDAU' had prefigured the park in the mid 1970s, defining an agricultural corridor linked to the wooded hillside and making the most of the fact that no construction was authorised underneath energy transport infrastructures. This space now remains virtually uncultivated, with the majority of the land being left fallow (Figure 7, no. 6). Recent wooded areas (Figure 7, no. 7), designed as carbon sinks, reconfigure the site. We can nevertheless see a certain number of rare permanencies of former landscape structures such as the bodies of water close to existing catchments (Figure 7, no. 8) and the roads, built spaces and grasslands further south (Figure 7, no. 9). Other previous structures can be found on the agricultural plain and in the urbanisation of a hamlet, the main characteristics of which are similar to those described in the following extract.

The third extract (Figure 8) relating to the Bourbre marsh and Chesnes agricultural plain, is characterised by gradual yet major changes due to the modernisation of cultivated spaces and to the development of residential urbanisation. The 1970 s planning documents provide a framework for these dynamics, which had begun much earlier. The restructuring of agricultural spaces to create field crops began in the 1960s, as evidenced by the crops that replaced the marsh grasslands between the 1960s and 1980s (Figure 8, no. 1), by the drying up of a branch of the river (Figure 8 , no. 2) and by the razing of the hedges (Figure 8 , no. 3). We can also see that the hillside grasslands have disappeared due to the decrease in livestock farming (Figure 8, no. 4). Nowadays however, we can see a certain number of permanencies such as hedge structures (Figure 8, no. 5) road structure (Figure 8, no. 6) and various remnants of grasslands on the hillsides (Figure 8, no. 7 ) and next to an old peat mining operation (Figure 8, no. 8). Environmental orientation can be identified here with the creation of grass filter strips as from 2005. Some of these were required, along the Bourbre, the former Bourbre and some marsh 
drainage ditches, in order to preserve the quality of their water (Figure 8, no. 9). Others were placed from time to time by the farmer on the agricultural plain, in order to have a sufficient area of ecological interest creating the right to certain subsidies (Figure 8, no. 10). In addition, there was a significant decrease in hedge clearance as from 2005. Urbanisation processes were marked by the uninterrupted construction of housing from the 1960s onwards (Figure 8, no. 11). The old roads were preserved and deadend service roads were built. This dynamic led to the disappearance of farmland, including grasslands and hedges (Figure 8, no. 12). We can also see that retention basins were built, including one that is entirely grasped, perhaps suggesting environmental sensitivity (Figure 8 , no. 13).

The evolution of the spaces presented in these extracts continues today. Several major ongoing agrinatural and planning management projects are underway (Figure 3 ), the main ones relating to the extension of the industrial estate (Figures 6, 7 and 8, area A), the construction of infrastructures for the Lyon-Turin high-speed train (Figure 7, area B) and a new road (Figure 8, area C), a plan for managing the marsh and part of the hillsides with an educational trail (Figure 8 , area D) and the renaturation of the Bourbre river (Figure 8 , area E). An analytical reading of the effects of the planning, made possible by the palimpsest mappings, gives pause for thought regarding future projects. How will they be embedded in the territorial heritage, in the context of current planning? What would be the benefits of an approach that effectively links the fields of ecology and landscape?

\subsection{A Visual Support for Outlining a Multifunctional Project}

This brings us to how these cartographic representations are used for interprofessional work, approached here through their appropriation by the CEN Isère and the CAUE Isère. We focus on these para-public structures that involved in our area of study, as they exist on a national scale to advise local actors in their respective fields of ecology and landscape architecture. The approach used in our particular case could therefore be adapted to suit other contexts.

In order to understand the operational benefits of this mapping tool in terms of the future of the territory, in 2018 and 2019 there were several meetings with CEN and CAUE personnel. In February and September 2019, two semi-directive interviews enabled us to clarify their respective visions. We therefore showed them the maps, their development and certain relevant aspects of analysis, and asked them how they thought it might help us to think about the development of future projects on open spaces. Of the two mapping panes, the pane 1 map (upper part of Figures 6, 7 and 8), which is more succinct, was the main one used for our discussions.

The experts made observations relating to the statement of project intent. This was based on their comple- mentary readings of the territory's history, suggested by the mappings of the palimpsest. The CEN has been concentrating on the development of field crops that has been taking place since the 1960s, leading to the disappearance of numerous grasslands, both dry and wet. What remains of these milieus could be conserved and redeveloped, so as to preserve the flora and fauna that depend on them-such as amphibians in the marshlands. Above and beyond these spaces considered to be reservoirs of biodiversity, the CEN points out that there is a group of elements that are part of the ecological network, for example hedges, grassy strips, retention basins linked to urbanisation, along with abandoned spaces and animal passageways near infrastructures. Current thinking focuses on ways to intensify them and to establish ecological management. The CAUE approaches these ordinary spaces via the history of urban expansion around former villages and hamlets, leading to the disappearance of a border of big gardens, vegetable gardens and grasslands around the built spaces. This border had previously ensured the relationship between the structure of the built and agricultural landscape with a diversity of vegetal structures and uses. These transitions now need to be reinterpreted, particularly in the context of ongoing urban extensions and infrastructures. The elements mentioned by the CEN might help with this if they are considered in relation to the uses and perceptions of the territory. Multifunctionality is one key to the development of a projet on open spaces and the CAUE also highlights its importance in recognised spaces of biodiversity, such as wet zones. The practice of hiking and the sensitive aspect of things such as the views over a waterway, a pond or grassland could be combined with ecology.

The aims of the CEN and CAUE lead us to take an interpretive look at the history of the territory in order to formulate orientations concerning it future that go beyond merely conserving small areas of biodiversity or simply landscaping a given development. If we base ourselves on elements of the local palimpsest to be intensified and reinterpreted, we will be able to sketch hypotheses for a multifunctional project on the ecological network. We propose to give an account of this for each of the three extracts. The wet grasslands of the former peat mining operation and of the grassy hillsides of extract 3 (Figure 8, no. 7 and no. 8) could be maintained or even redeveloped alongside the projects around the Bourbre river (Figure 8, areas $D$ and E), whilst taking different uses and local memory into consideration. The borders of the new infrastructures and of the future urbanisation of extracts 2 and 3 (Figures 7 and 8 , areas A, B and C) could be worked with pathways and with plant-covered and hydraulic structures intersecting with the existing network of roads, hedges, grassy strips, fallow lands and woods (Figure 7, no. 6 and no. 7, Figure 8, no. 5, no. 6 and no. 10). Incentives to strengthen these pre-existing semi-natural elements could be offered during this process. Such a project would develop ecological functionality, especially as it would combine with animal passage- 


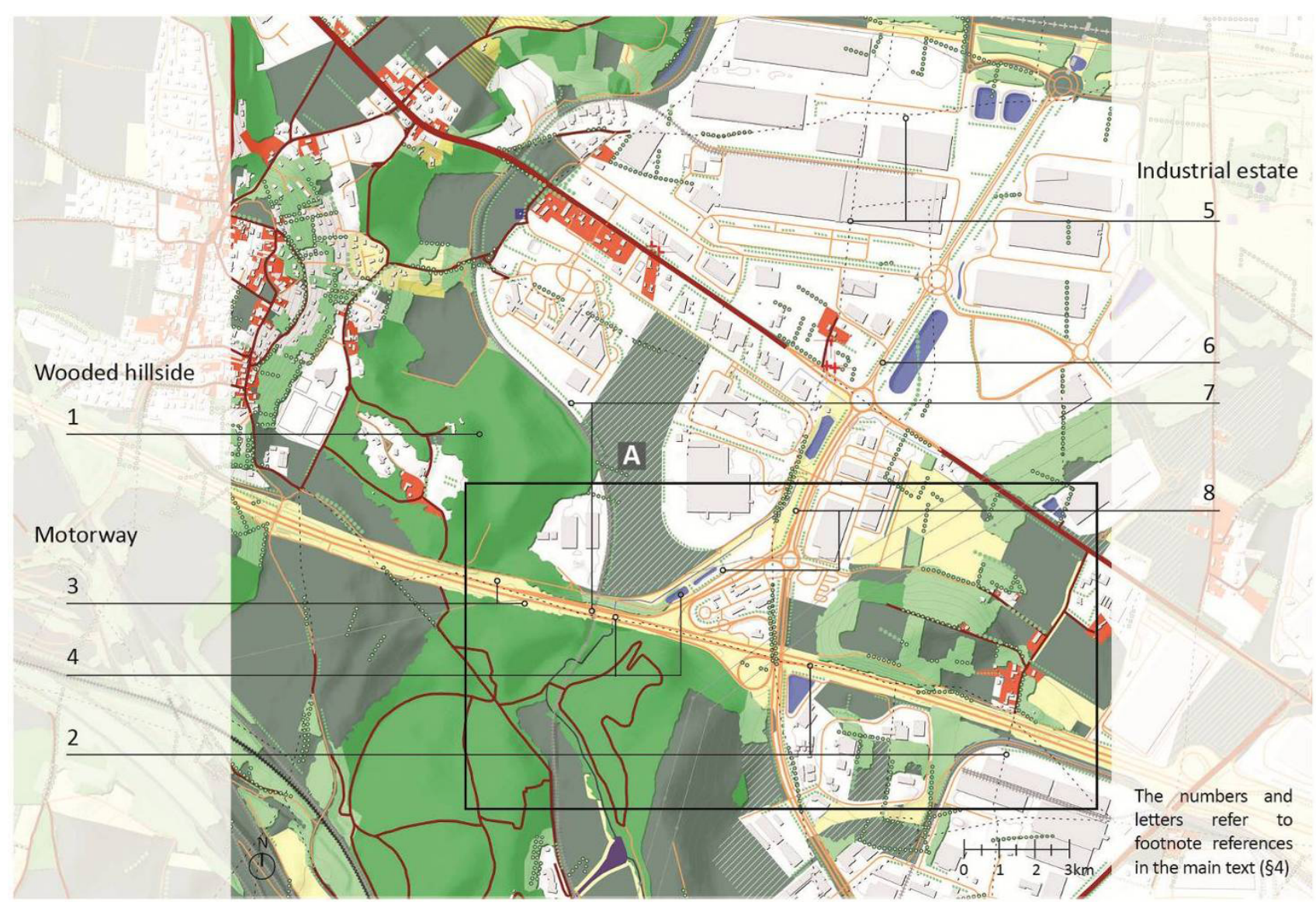

Pane 1: 1960-2020 and ongoing projects

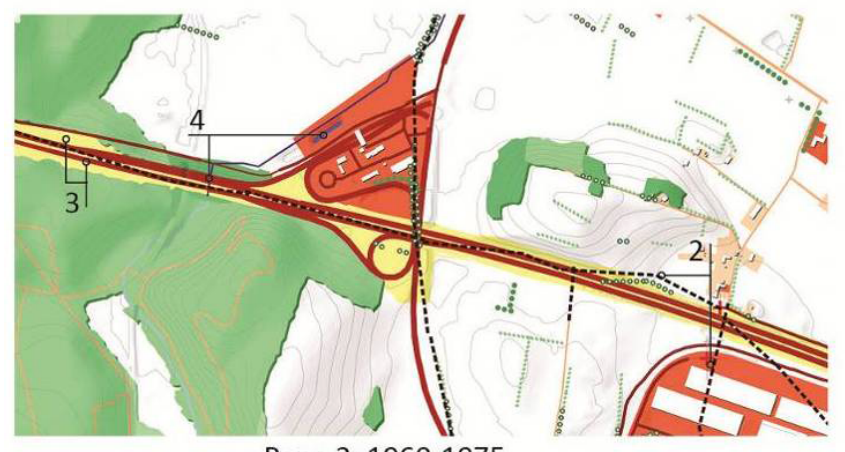

Pane 2: 1960-1975

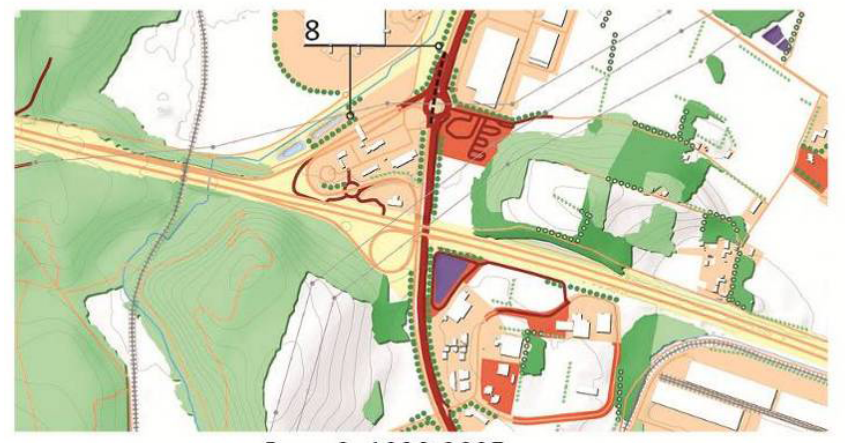

Pane 2: 1990-2005

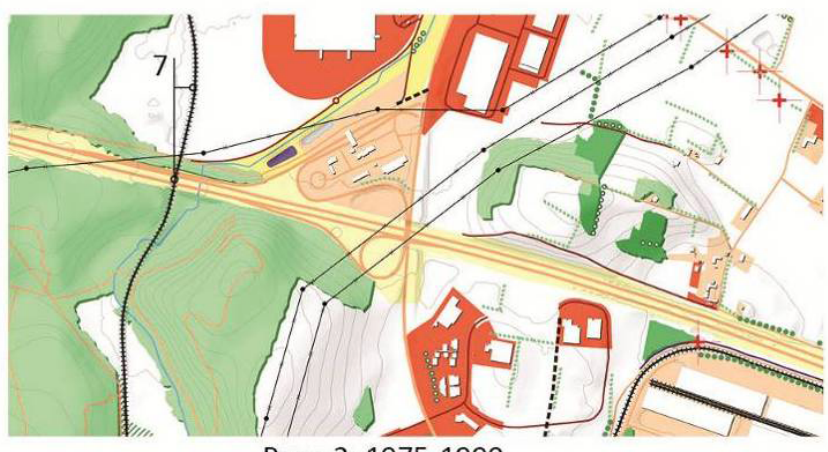

Pane 2: $1975-1990$

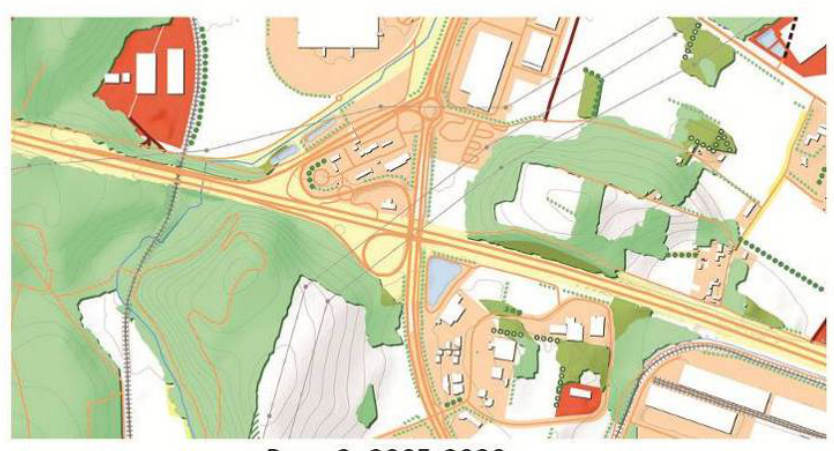

Pane 2: 2005-2020

Figure 6. Extract 1 from the palimpsest mapping: The wooded hillside Grenay (east of the industrial estate). Source: Author. 


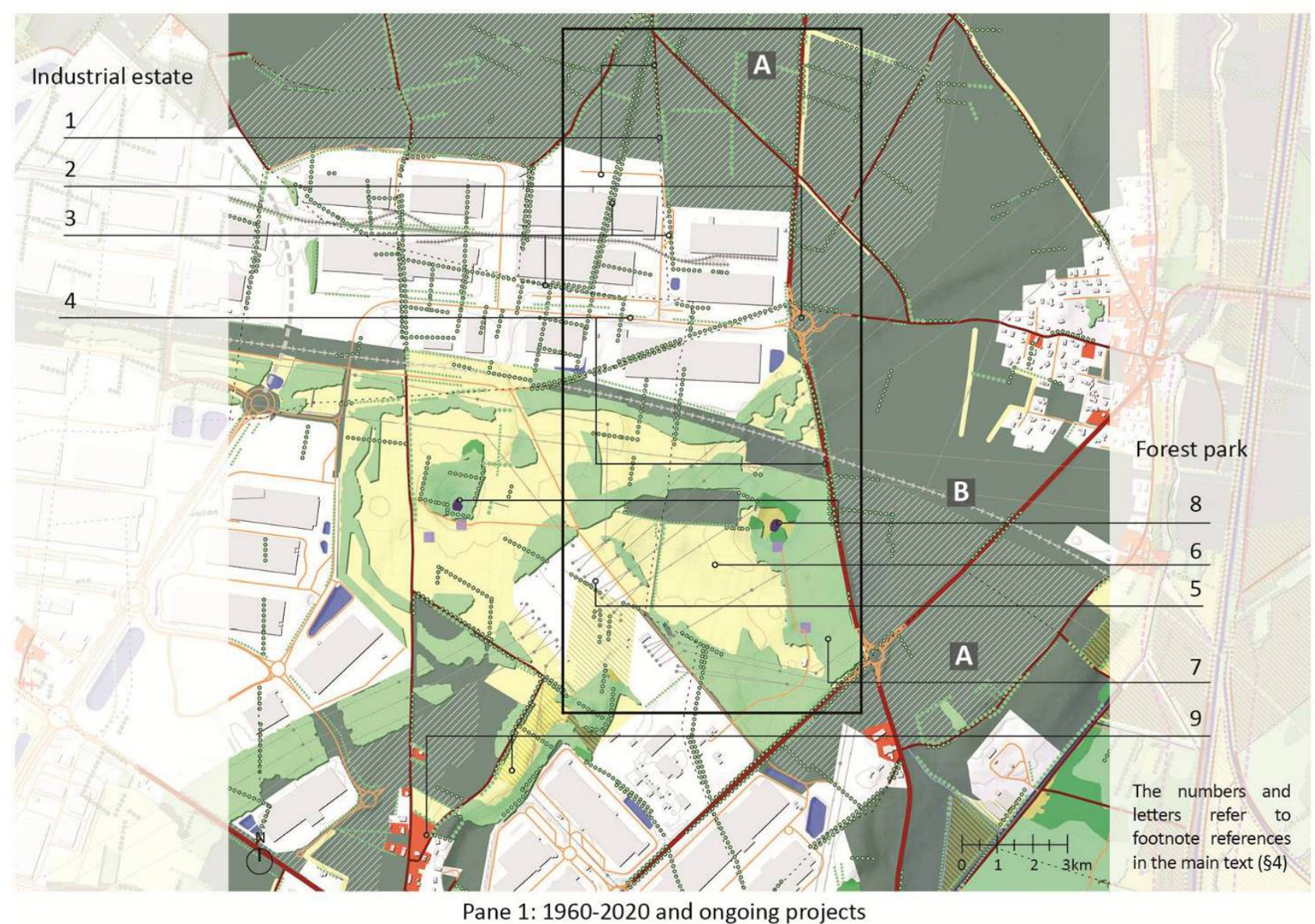

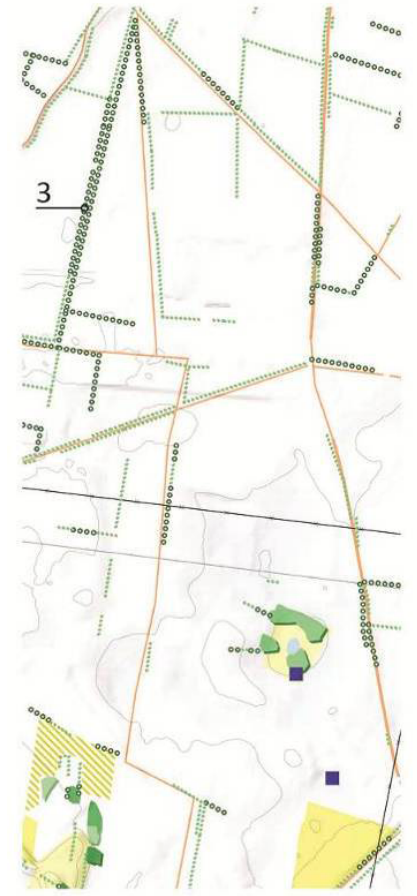

Pane 2: 1960-1975

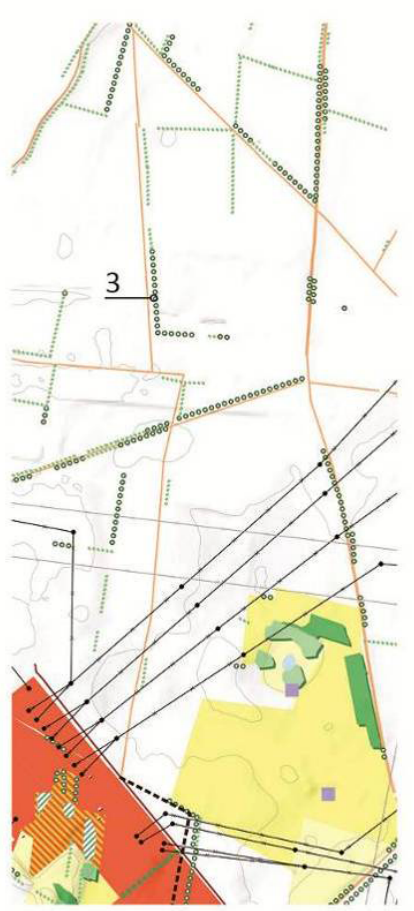

Pane 2: 1975-1990

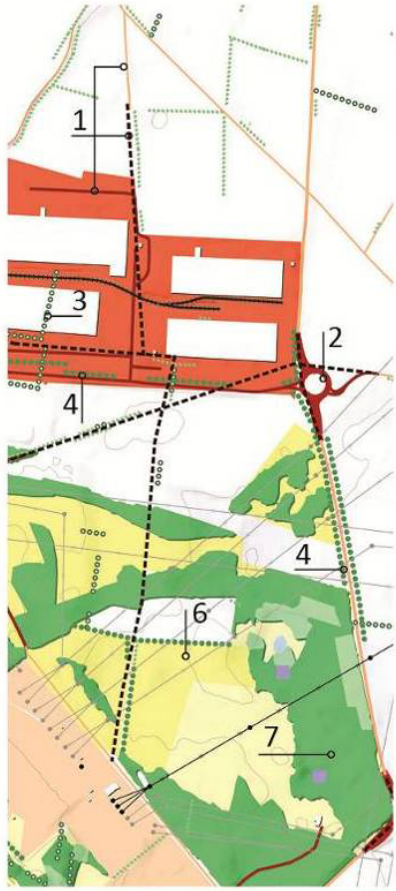

Pane 2: 1990-2005

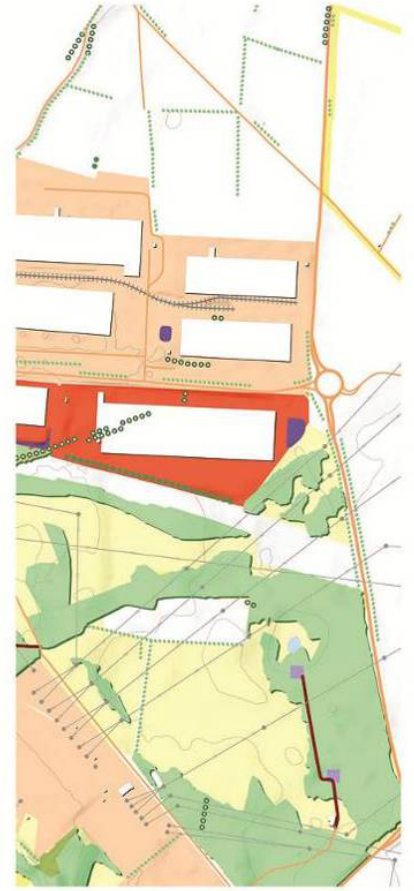

Pane 2: 2005-2020

Figure 7. Extract 2 from the palimpsest mapping: The industrial estate forest park. Source: Author. 


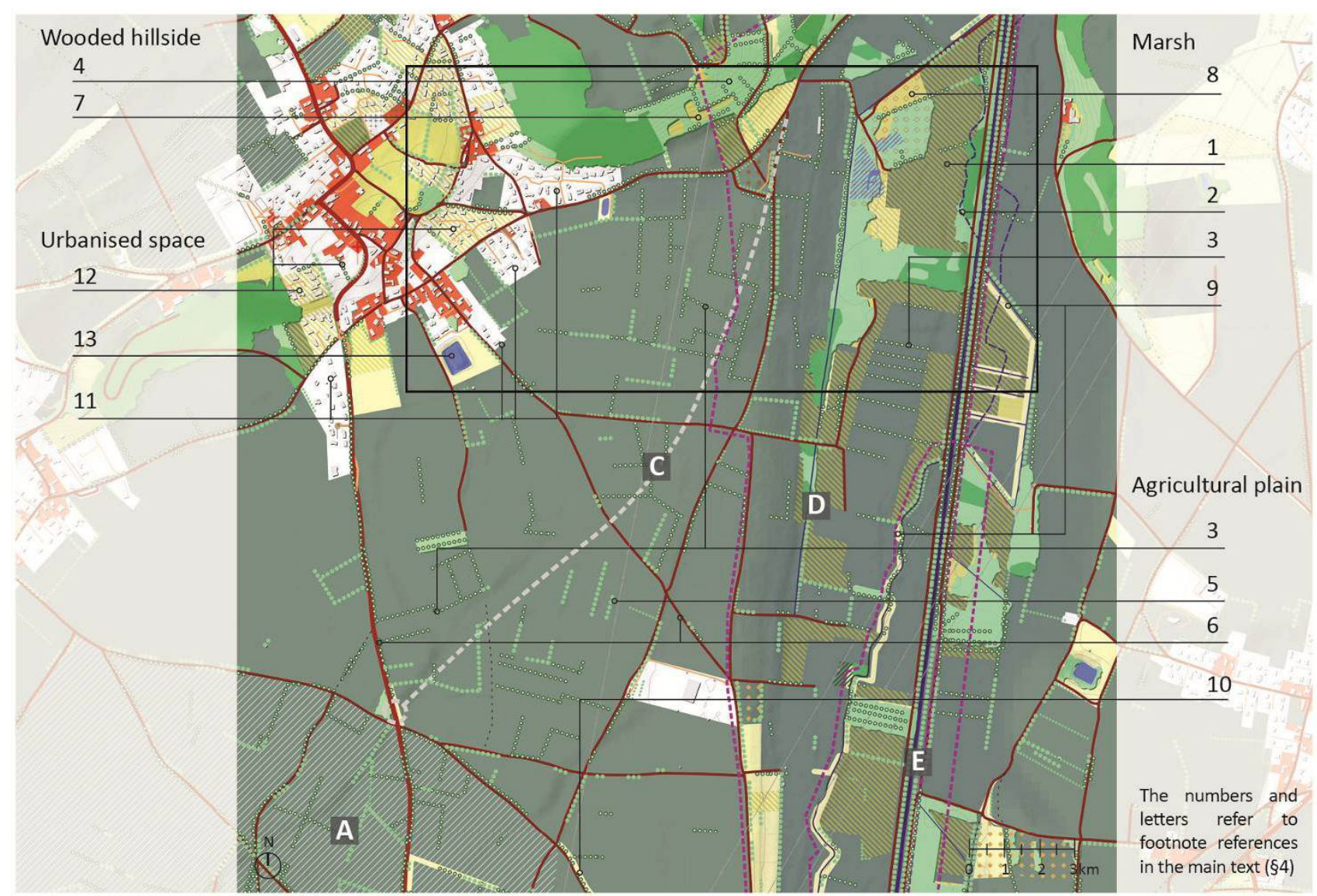

Pane 1: $1960-2020$ and ongoing projects

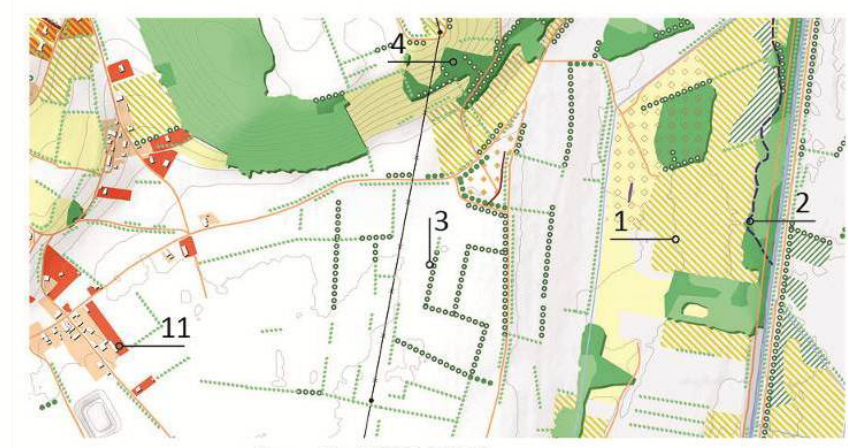

Pane 2: 1960-1975

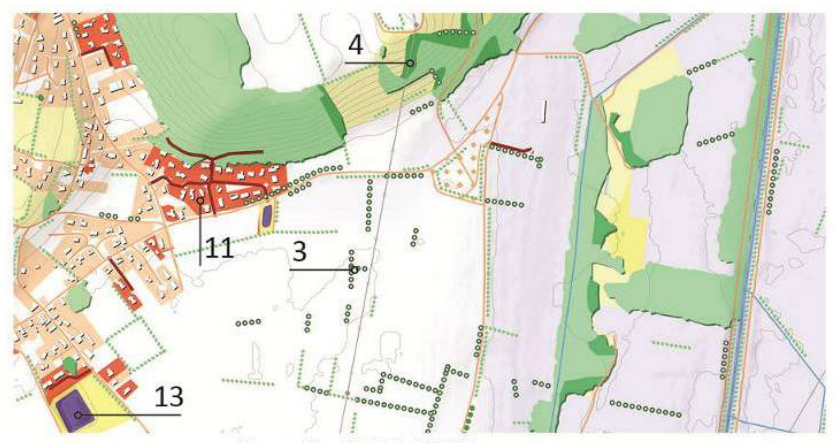

Pane 2: 1990-2005

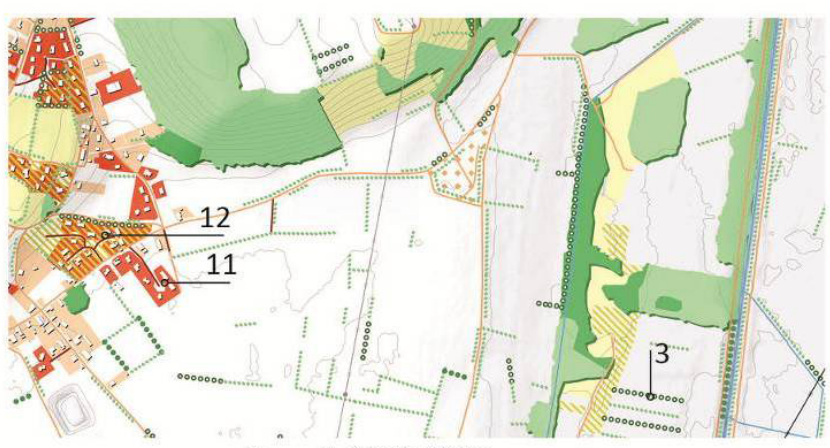

Pane 2: 1975-1990

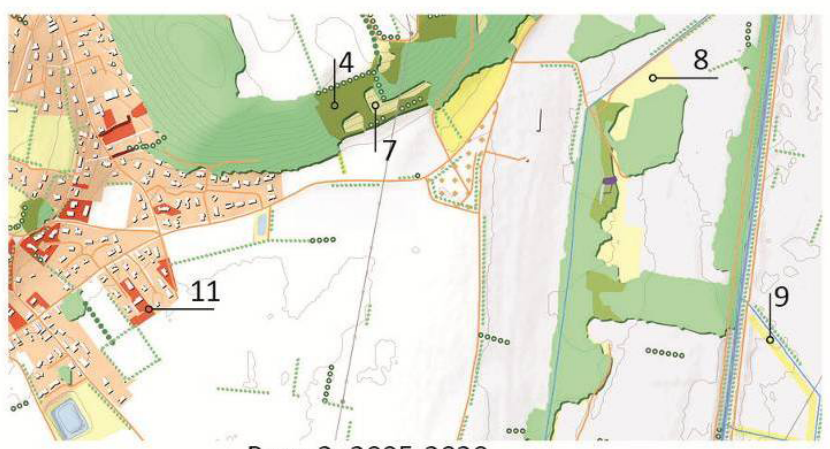

Pane 2: $2005-2020$

Figure 8. Extract 3 from the palimpsest mapping-The Chesnes agricultural plain (north of the industrial estate). Source: Author. 
ways with which to cross the main roads, and with suitable choices regarding plant species and management. It would also lead to a qualitative perception of developments through the transitions made with the agricultural space and the forest park-reinterpreting the former agri-urban borders-and to new practices (agricultural, leisure, etc.). Regarding extract 1 , the under-used railway line at the foot of the hillside (Figure 6, no. 7) and the retention basins of the planted road that follows the channelled stream (Figure 6, no. 4, no. 6 and no. 8) constitute a potential that could be explored so as to create ecological and landscape connections with the forest park. Such a link would follow the geography of the site and would provide a motorway crossing for both fauna and human beings. The end of the urbanisation east of the industrial park (Figure 6, area A) might benefit from this type of reflection.

\subsection{A Visual Support for the Co-Construction of a Project with Local Actors}

The CEN and CAUE highlight another aspect concerning the potential of the palimpsest maps, that of opening up a dialogue with a broad public (elected officials, inhabitants, etc.) on the matter of the territory's history and future. This is an interesting dimension with regard to the co-construction of a multifunctional project, including the appropriation of the notion of ecological networks by local actors. There is feedback to support this idea. The CEN ecologist explains how he frequently uses old aerial photographs from different periods (1940s, 1960s, 1980s, 2000s) with a brief photo-interpretation of the evolution of wooded areas and grasslands. This makes it possible to talk to elected officials about the types of space that they would like to see in the future, and indirectly about the species that might prosper there. These actors prefer this type of approach to a lecture on the conservation of species of animals and plants. Local inhabitants generally prove to be just as receptive to a temporal reading of the space. On this matter the CAUE landscape architect refers to a portrait of the history of a municipality that she helped the inhabitants to draw. There was a simultaneous dialogue with local officials, to reflect upon territorial developments. The mapping tool that was developed thus offered a potential to engage in a multi-actor dialogue. With this objective in mind, the CAUE has set out paths for development. It would be useful to create complementary supports relating to cartographies, such as photographs, to enhance exchanges with local actors. Quantitative figures available from GIS could also be used.

The CAUE also mentioned possible follow-ups to this work. This raises the issue of both collaborations between academic research and operational development, and between the structures that can support this type of cartographic approach associated with mediation between actors. Would it be possible to develop a partnership between the CEN and the CAUE? In our inter- territorial context, which is characteristic of rural-urban metropolitan areas, might our proposal contribute to cooperation mechanisms of an 'Inter-SCOT' type (Dugua, 2015)? Could urban planning agencies developing cartographic observatories (Loubière et al., 2007), including historical ones, pilot such work?

\section{Conclusion: Palimpsest Mappings as 'Intermediary Objects'}

Our article proposes a methodology for mapping the palimpsest of milieus as an 'intermediary object' in order to develop a shared multifunctional project on open spaces. These maps are collective visualisation tools that can be used to reflect upon the geography and the temporal depth of space, in terms of both environment and landscape in response to the challenges of contemporary projects (Delbaere \& Pousin, 2011). The palimpsest mapping experiment highlights the benefit of this tool to encourage discussions about the possible futures of the territory, by calling upon territorial heritage. It is a potential common support between professionals when defining the intent of a multifunctional project, and to generate interest and collaboration between actors, using retroprospective narrative (Sgard, 2008).

Elements of the method used for the Plaine SaintExupéry could be adapted to other contexts. In conclusion, one of the processes that we wish to highlight is the 'work of equipment' carried out to link heterogeneous social worlds (Vinck, 2009; Vinck \& Jeantet, 1995). It stems from the wish to combine the approach of ecological experts with that of landscape experts so as to define a multifonctional projet on open spaces that can involve different partners. After analysing the two professional practices we had targeted, we put forward the hypothesis of the utility of a cartographic representation of time. We focused on the planned evolutions, since 1960, of certain territorial components likely to be of interest to them. The resulting legends and temporal frame thus 'equip' the maps to make the required dialogue possible. The alignment of the CEN's and CAUE's views then specifies how the mapping tool might be used to co-construct a shared multifunctional project. When the CAUE suggests completing the maps with photographs or quantitative data, in order to facilitate discussions with the different actors (elected officials, local inhabitants, farmers, etc.), we can see the desire for an additional 'equipment' with which to strengthen the dialogical interactions made possible by this 'intermediary object.'

In order to refine the proposed methods and tools, along with their benefits and limits, it would be necessary to first develop the perspectives that emerge in the context of the Plaine Saint-Exupéry. We are currently working on a paper which will discuss some of these aspects (Callens, 2020). Secondly, this type of approach would benefit from being used in other territories. The capacity of this 'intermediary object' to connect different local actors could thus be tested. Moreover, we would be 
able to verify its utility with regard to interprofessionality. Such work would also benefit from being extended to deal with the diverse problems that arise, in relation to agronomics, hydrology, ethno-ecology and infrastructure engineering. Where necessary, these situations would allow the mapping of palimpsests to evolve, using layers relating to new themes (pedology, water tables, vegetation in urbanised spaces, parcel boundaries, etc.), from other data production techniques (remote sensing, participatory maps, etc.), with new methods for making maps and possible combinations with other representations (photography, etc.). Developments like these would expand the horizons of palimpsest mapping highlighted in this article.

\section{Acknowledgments}

I would like to thank local stakeholders in the Plaine Saint Exupéry in Lyon, and in particular the SMABB, CAUE Isère and CEN Isère, for their collaboration during the fieldwork. I am also very grateful to Frédéric Pousin for his advice, to IPRAUS for their support, and to the EPFL Habitat Research Center for their contribution to the editing process. Finally, I would like to thank the Urban Planning editorial team and the anonymous referees for their precious advice.

\section{Conflict of Interests}

The author declares no conflict of interests.

\section{References}

Ahern, J. (1991). Planning for an extensive open space system: Linking landscape structure and function. Landscape and Urban Planning, 21(1), 131-145. https://doi.org/10.1016/0169-2046(91)90037-M

Amsallem, J., Sordello, R., Billon, L., \& Vanpeene, S. (2018). Bilan des Schémas régionaux de cohérence écologique en France: Quels apports méthodologiques pour l'identification et la cartographie de la Trame verte et bleue? [Summary of the regional scheme for ecological coherency in France: What methodological contributions for the identification and mapping of the green and blue network?]. Sciences Eaux et Territoires, 25, 4-11. https://doi.org/10.14758/SET-REVUE.2018.25.01

APCE. (2016). Paysage et trame verte et bleue (Rapport du groupe de travail "paysage et trame verte et bleue") [Landscape architecture and green and blue network (Report by the Landscape Architecture and Green and Blue Network Working Group)]. Versailles: Association des paysagistes-conseils de l'Etat. Retrieved from http://www.paysagistesconseils.org/sites/apce/files/contenus/rapport_ ptvb_11_02_2017_0.pdf

APCE. (2018). Vers un système d'information sur les paysages (rapport du groupe de travail "Système d'information sur les paysages: La donnée de paysage dans tous ses états") [Towards a landscape information system (report by the Landscape Information System: Landscape Data in All Its Forms Working Group)]. Versailles: Association des paysagistesconseils de l'Etat. Retrieved from http://www. paysagistes-conseils.org/sites/apce/files/contenus/ apce_rapport_sip_2018_0.pdf

Autran, S. (2004). Les infrastructures vertes à l'épreuve des plans d'urbanisme: L'agglomération lyonnaise, la construction d'une stratégie [Green infrastructures put to the test of urban planning plans: The Lyon urban area, building a strategy]. Lyon: CERTU.

Bédarida, M. (2002). L'Isle-d'Abeau: Territoire entre Rhône et Isère [Isle-d'Abeau: Territory between Rhône and Isère]. Paris: Hartmann.

Bellec, A., Gauthiez, B., Fenet, S., \& Kaufmann, B. (2019). Webarmature: Observatoire diachronique du territoire lyonnais [Webarmature: Diachronic observatory of the Lyon area]. Cybergeo: European Journal of Geography. https://doi.org/10.4000/cybergeo. 32652

Burel, F., \& Baudry, J. (1999). Écologie du paysage: Concepts, méthodes et applications [Landscape ecology: Concepts, methods and applications]. Paris, London, and New York, NY: Tec \& Doc.

Callens, A. (2020). La recherche, source du renouvellement de l'expertise paysagère. Retour sur une expérimentation concernant les espaces ouverts de la plaine Lyon-Saint-Exupéry [Research, source of the renewal of landscape architecture expertise. A look back at an experiment concerning the open spaces of the Lyon-Saint-Exupéry plain]. Manuscript submitted for publication.

Callon, M., Burchell, G., Lascoumes, P., \& Barthe, Y. (2011). Acting in an uncertain world: An essay on technical democracy. Cambridge, MA: MIT Press.

Corboz, A. (1983). The land as palimpsest. Diogenes, 31(121), 12-34. https://doi.org/10.1177/ 039219218303112102

Corboz, A. (2001). La description: Entre lecture et écriture [Description: Between reading and writing]. In Le territoire comme palimpseste et autres essais [The land as a palimpsest and other essays]. Besançon: Éditions de l'imprimeur.

Décamps, H., \& Décamps, O. (2004). Au printemps des paysages [In the spring of landscapes]. Paris: BuchetChastel.

Delbaere, D., \& Pousin, F. (2011). Éditorial: Paysage et environnement. Quelle mutation des projets d'aménagement? [Editorial: Landscape and environment. What changes to development projects?]. Espaces et societes, 146(3), 7-15.

Donadieu, P. (1998). Campagnes urbaines [Urban countrysides]. Arles: Actes Sud.

Dugua, B. (2015). Entre mise en oeuvre et mise à l'épreuvre de la planification territoriale: Dynamique des lieux de projets dans l'inter-Scot de l'aire 
métropolitaine lyonnaise [Between implementation and testing territorial planning: Dynamics of project locations in the inter-Scot of the Lyon metropolitan area] (Unpublished Doctoral thesis). Université Grenoble Alpes, France. Retrieved from http://www. theses.fr/193750244

ECOVIA. (2016). Etude préalable au contrat vert et bleu de la Bourbre [Preliminary study for the Bourbre green and blue network contract]. Lyon: ECOVIA.

Forestier, J.-C.-N. (1906). Grandes villes et systèmes de parcs [Large cities and park systems]. Paris: Hachette et Cie. Retrieved from https://gallica.bnf.fr/ ark:/12148/bpt6k9656489n

Forman, R. T. T., \& Godron, M. (1986). Landscape ecology.Chichester: J. Wiley \& Sons .

Franchomme, M., \& Dubois, J.-J. (2010). Documenter les zones humides: Vers une meilleure compréhension des paysages d'eau du XIXe au XXes [A documentary study of humid zones: Towards a better understanding of wetland landscapes from the 19th to the 20th century]. Géocarrefour, 85(1), 7-16. https://doi.org/ 10.4000 /geocarrefour.7622

Girel, J. (2006). Quand le passé éclaire le présent: Écologie et histoire du paysage [When the past sheds light on the present: Ecology and history of landscapes]. Géocarrefour, 81(4), 249-264. https://doi. org/10.4000/geocarrefour.1622

Gras, P. (1995). Révélateurs de ville, Lyon, travaux récents de l'agence d'urbanisme [City revealers, Lyon, recent work by the urban planning agency]. Liège: Mardaga.

Jongman, R. H. G., Külvik, M., \& Kristiansen, I. (2004). European ecological networks and greenways. Landscape and Urban Planning, 68(2), 305-319. https://doi.org/10.1016/S0169-2046(03)00163-4

Khirfan, L. (2010). Traces on the palimpsest: Heritage and the urban forms of Athens and Alexandria. Cities, 27(5), 315-325. https://doi.org/10.1016/ j.cities.2010.03.009

Lefeuvre, J. C. (1999). Des paysages passés aux paysages anthropisés actuels [From past landscapes to current anthropized landscapes]. In F. Burel \& J. Baudry (Eds.), Écologie du paysage: Concepts, méthodes et applications (pp. XVII-XXX). Paris, London, and New York, NY: Tec \& Doc.

Léveillé, A., Corboz, A., Cassani, Y., Mayor, M.-P., ToumiOverney, I., \& Hirschi, P. (1993). Atlas du territoire genevois: Permanences et modifications cadastrales aux XIXe et XXe siècles [Atlas of the Geneva territory: Permanences and cadastral changes in the 19th and 20th centuries]. Geneve: Département des travaux publics du canton de Genève, Service des monuments et des sites, Centre de recherche sur la rénovation urbaine.

Loubière, A., Frérot, O., Roussel, O., Rolland, S., Jessel, R., Simard, P., \& Vanier, M. (2007). Représentation et "grand territoire": Le chantier lyonnais [Representation and "large territory": The Lyon construction site]. Urbanisme, 357, 44-54.
Magnaghi, A. (2014). La biorégion urbaine: Petit traité sur le territoire bien commun [The urban bioregion: Short treatise on the common good]. Paris: Eterotopia France.

MEEDDM. (2010). Choix stratégiques de nature à contribuer à la préservation et à la remise en bon état des continuités écologiques [Strategic choices likely to contribute to the preservation and restoration of ecological continuity]. Paris: Ministère de l'Écologie, de l'Énergie, du Développement Durable et de la Mer. Retrieved from http://www.trameverteetbleue.fr/ documentation/references-bibliographiques/choixstrategiques-nature-contribuer-preservation-remise

Nassauer, J. (1992). The appearance of ecological systems as a matter of policy. Landscape Ecology, 6(4), 239-250. https://doi.org/10.1007/BF00129702

OREALM, \& PAYSA. (1975). Le paysage rural et régional: Contribution à la méthodologie des études d'aménagement [Rural and regional landscape: Contribution to the methodology of planning studies]. Paris: Documentation française.

Pernet, A. (2014). Le grand paysage en projet: Histoire, critique et expérience [Large landscapes in projects: History, criticism and experience]. Geneve: MétisPresses.

Poli, D. (2018). Formes et figures du projet local, la patrimonialisation contemporaine du territoire [Forms and figures of the local project, the contemporary patrimonialization of the territory]. Paris: Eterotopia.

Pousin, F., Marco, A., Bertaudière-Montès, V., Barthélémy, C., \& Tixier, N. (2016). Le transect: Outil de dialogue interdisciplinaire et de médiation. Le cas du projet d'élargissement de la 3e voie ferrée de la vallée de l'Huveaune (France) [Transects: A tool for interdisciplinary dialogue and mediation. The case of the project to widen the 3rd railway line in the Huveaune valley (France)]. VertigO, 24. https://doi.org/10.4000/vertigo.17372

Préfecture de région Rhône-Alpes. (2006). Directive territoriale d'aménagement de l'aire métropolitaine lyonnaise [Territorial planning directive for the Lyon metropolitan area]. Préfecture de région RhôneAlpes. Retrieved from http://www.auvergne-rhonealpes.developpement-durable.gouv.fr/dta-de-Iaire-metropolitaine-lyonnaise-a10970.html

Raymond, R., Luginbühl, Y., Seguin, J.-F., \& Cedelle, Q. (2015). Landscape Atlases: Landscape identification, characterisation and assessment method. Paris: Ministère de l'Écologie, du Développement durable et de l'Énergie. Retrieved from https://www.ecologiquesolidaire.gouv.fr/sites/default/files/Landscape\% 20Atlases\%2C\%20Landscape\%20identification\% 2C\%20characterisation\%20and\%20assessment\% 20method.pdf

Sgard, A. (2008). Entre rétrospective et prospective [Between retrospective and prospective]. EspacesTemps. Retrieved from https://www.espacestemps. net/articles/entre-retrospective-et-prospective 
Sieverts, T. (2003). Cities without cities: An interpretation of the Zwischenstadt. New York, NY: Routledge.

TEREO. (2016). Trame verte: Complément des connaissances existantes et diagnostic de territoire [Trame verte: Complement of existing knowledge and diagnostic of territory]. Sainte-Hélène-du-Lac : TEREO.

Tiberghien, G. A. (2013). Du dessin [About drawing]. Les carnets du paysage, 24, 5-8.

Vinck, D. (2009). De l'objet intermédiaire à l'objetfrontière [From the intermediary object to the boundary object]. Revue d'anthropologie des connaissances, 3(1), 51-72. https://doi.org/10.3917/rac.
006.0051

Vinck, D., \& Jeantet, A. (1995). Mediating and commissioning objects in the sociotechnical process of product design: A conceptual approach. In D. Vinck, D. MacLean, \& P. Saviotti (Eds.), Management and new technology: Design, networks and strategy (pp. 111-129). Grenoble:COST Social Science Series.

Zarmati, S. (1980). Landscape practice and methodology in the French planning process. Landscape Planning, 7(3), 203-221. https://doi.org/10.1016/03043924(80)90023-4

\section{About the Author}

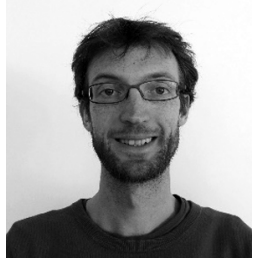

Alexandre Callens received his degree in Architecture from the Paris-La-Villette School of Architecture in 2007 and a master's degree in Landscape Architecture from the Versailles School of Landscape Architecture in 2014. He is currently writing his PhD thesis under the supervision of Frédéric Pousin at the IPRAUS/AUSSER research unit in the Paris-Belleville School of Architecture. He teaches in this school, as well as at Paris-Est University. His research relates to expertise on landscape architecture and to the role of inter-professionalism in land-use planning and ecological transition processes. 